Doi: 10.35414/akufemubid.387249

\author{
Araştırma Makalesi / Research Article
}

\title{
Farklı Ortam Koşullarının Micrococcus sp. Ekzopolisakkarit Üretimine Etkisi
}

\author{
Nur Koçberber KILIÇ ${ }^{1 *}$, Gönül DÖNMEZ ${ }^{1}$ \\ ${ }^{1}$ Ankara Üniversitesi, Fen Fakültesi, Biyoloji Bölümü, Beşevler, 06100, Ankara, TÜRKIYE. \\ *nrkilic@ankara.edu.tr. ID: http://orcid.org/0000-0003-2668-3789 \\ gdonmez@ankara.edu.tr. ID: http://orcid.org/0000-0001-7972-5570
}

Geliş Tarihi: 31.01.2018 ; Kabul Tarihi: 25.02.2019

Öz

Anahtar kelimeler

Micrococcus sp., Ekzopolisakkarit (EPS),

Remazol Blue, Atık su

\begin{abstract}
Endüstriyel atık sulardan izole edilen Micrococcus sp. ile yapılan çalışmada, farklı pH değerlerinin, Remazol Blue konsantrasyonlarının, sıcaklık derecelerinin ve inkübasyon sürelerinin bakterinin ürettiği ekzopolisakkarit (EPS) miktarına etkisi araştırılmıştır. Remazol Blue bulunan ortamlarda farklı pH'larda (pH 6-9) $30^{\circ} \mathrm{C}$ de gerçekleştirilen deneylerde, $\mathrm{pH} 6^{\prime}$ da yüksek miktarda EPS üretildiği belirlenmiştir. Bakteri 100-400 mg/l arasındaki başlangıç Remazol Blue konsantrasyonlarında $\left(\mathrm{pH} 6,30^{\circ} \mathrm{C}\right.$ ) en iyi EPS üretimini, $200 \mathrm{mg} / \mathrm{l}$ Remazol Blue konsantrasyonunda $234.8 \mathrm{mg} / \mathrm{l}$ olarak yapmıştır. Artan sıcaklık derecelerinin Micrococcus sp. tarafından üretilen EPS miktarlarına etkisinin araştırıldığı denemelerde ise en yüksek EPS üretimine $40^{\circ} \mathrm{C}^{\prime}$ de ulaşıldığı görülmüştür. İnkübasyon süresinin üretilen EPS miktarına etkisi araştırıldığında, artan inkübasyon süresinin EPS üretimini azalttığı, en yüksek EPS üretimine biyokütle üretiminin yeni başladığı 48 saatlik inkübasyon süresi sonunda ulaşıldığı belirlenmiştir. Denemeler sonunda en yüksek EPS üretimi, pH 6' da, $100 \mathrm{mg} / \mathrm{l}$ Remazol Blue içeren ortamda, $40^{\circ} \mathrm{C}^{\prime} \mathrm{de}$ ve 48 saat inkübasyon süresi sonrasında $257.2 \mathrm{mg} / \mathrm{l}$ olarak elde edilmiştir.
\end{abstract}

\section{The effect of different environmental conditions on exopolysaccharide production of Micrococcus sp.}

\author{
Keywords \\ Micrococcus sp., \\ Exopolysaccharide \\ (EPS), Remazol Blue, \\ Wastewater
}

\begin{abstract}
The effect of different $\mathrm{pH}$ values, temperature degrees, Remazol Blue concentrations and incubation periods on exopolysaccharide (EPS) production of the bacteria was investigated in this study which was performed with Micrococcus sp. isolated from industrial wastewater. In trials at $30^{\circ} \mathrm{C}$ including Remazol Blue with different $\mathrm{pH}(\mathrm{pH} 6-9)$, the production of high amount of EPS was found at $\mathrm{pH} 6$. At initial Remazol Blue concentrations between $100-400 \mathrm{mg} / \mathrm{l}\left(\mathrm{pH} 6,30{ }^{\circ} \mathrm{C}\right)$, the bacteria was produced the maximum EPS production at $200 \mathrm{mg} / \mathrm{l}$ Remazol Blue as $234.8 \mathrm{mg} / \mathrm{l}$. In trials to investigate the effect of increasing temperature degrees on EPS amount produced by Micrococcus sp., it is observed that the maximum EPS production was reached at $40^{\circ} \mathrm{C}$. When the effect of incubation period on production of EPS was investigated, increasing incubation period was decreased EPS production, the highest EPS production was determined at the end of $48 \mathrm{~h}$ incubation period in which biomass production has just begun. At the end of the trials, the maximum EPS production was found at $\mathrm{pH} 6$, in media including 100 $\mathrm{mg} / \mathrm{l} \mathrm{Remazol}$ Blue at $40^{\circ} \mathrm{C}$ and at the end of $48 \mathrm{~h}$ incubation period as $257.2 \mathrm{mg} / \mathrm{l}$.
\end{abstract}

\section{Giriş}

Tekstil, deri ve kağıt endüstri kollarının oluşturduğu atık sular kontrolsüz bir şekilde akarsulara ve denizlere deşarj edildiğinde bu sularda yaşayan canlı topluluklarına oldukça toksik etki yapmaktadırlar.
Ayrıca, tekstil endüstrisi atık sularındaki sentetik boyar maddeler, ışı̆̆ın geçmesini engelleyerek akuatik yaşamdaki fotosentetik aktiviteyi negatif yönde etkilemektedir (Aksu, 2005). Bu tip sular bahsedilen özelliklerinden arıtılmalıdırlar. Boya 
içeren atık suların arıtımı ile ilgili birçok farklı teknik kullanılmaktadır. Bunlar arasında biyolojik arıtım, çöktürme-floklaştırma, elektrokimyasal işlemler, ozon arıtımı, ters ozmoz ve mikrofiltrasyon gibi yöntemler bulunmaktadır (Allegre et al. 2006, Crini, 2005).

Daha önce yapılan çalışmalarda, biyolojik arıtım yoluyla boya giderimi yapabilen mikroorganizmalar izole edilmiştir (Aksu and Dönmez 2005, Khehra et al. 2006, Sadettin and Dönmez 2006, Kılıç et al. 2007, Lodato et al. 2007, Bouraie and Din 2016, Mishra and Maiti 2018). Mikroorganizmalarca üretilen EPS, bakterilerin birlik oluşturarak floklaşmasında, biyofilm üretmesinde ve bu yapının stabil kalmasını sağlamada korucuyu bir tabaka gibi görev görür (Flemming et al. 2016). Bu özelliği ile EPS, toksik kontaminantların endüstriyel atık sulardan biyogideriminde etkili olmaktadır (Aksu 2005, Khehra et al. 2006, Zhang et al. 2006). Daha çok ağır metal gibi iyonlara karşı üretildiği ve metal kelasyonu (lyer et al. 2004, Guibaud et al. 2005, Ozdemir et al. 2003, Mohite et al. 2017, Gupta and Diwan 2017) ile ilgili olarak bilinen EPS'nin, bahsedilen özelliklerinden reaktif boyar maddelere karşı da oluşturulabileceği düşünülmektedir.

Ağır metallerin EPS yardımı ile ortamdan uzaklaştırılmaları birçok çalışmada açıklandığı halde, reaktif boyar maddeler ve buna karşı oluşturulan EPS üretimi konusunda çok az çalışma yapılmıştır. Boyar maddelerin biyolojik yollarla giderimleri Pseudomonas luteola (Chen 2002) ve Stenotrophomonas sp., Pseudomonas sp., Bacillus sp. (Khehra et al. 2006) gibi mikroorganizmalarca gerçekleştirilmiştir. Ayrıca, Paenibacillus polymyxa, Micrococcus luteus ve Micrococcus sp. gibi üç mikroorganizmanın karıştırılarak kullanıldığı bir karışımla da boyar maddelerin ortamdan uzaklaştırıldığı belirtilmiştir (Moosvi et al. 2007).

Boya giderimi yapan bazı mikroorganizmaların EPS ürettikleri bilinmektedir (Shah et al. 1999, Chen 2002, Lodato et al. 2007). Fakat bu çalışmalarda toksik boyalara karşı ne miktarda EPS üretildiği belirlenmemiş ve EPS'nin hangi çevresel koşullardan ne derece etkilendiği belirtilmemiştir. Yapılan çalışmada, farklı pH derecelerinin, sıcaklığın, başlangıç Remazol Blue konsantrasyonlarının ve inkübasyon süresinin Micrococcus sp. tarafından üretilen EPS miktarına etkisi araştırılmıştır.

\section{Materyal ve Metot}

\subsection{Bakteri kültürü}

Deri sanayi atık sularından (Sepiciler Deri Fabrikası, İzmir) izole edilerek kullanılan bakteri, araştırıcıların daha önceki bir çalışmasında Micrococcus sp. olarak tanılanmıştır (Kılıç and Dönmez 2007).

\subsection{Boya solüsyonu}

Çalışmada kullanılan boya (Remazol Blue) Aytemizler Tekstil Fabrikası'ndan (Ankara) saf halde alınmıştır. Stok solüsyon, toz haldeki kimyasalın \%2 (w/v) konsantrasyon olacak şekilde distile suda çözülmesiyle hazırlanmıştır. Stok solüsyondan istenilen konsantrasyonlar, Nutrient Agar besiyerine eklenmiştir.

\subsection{EPS üretimi}

EPS üretiminin belirlenmesi için bakteri kültürü petrilerde hazırlanmış Nutrient Agar besiyerlerinde geliştirilmiştir. Besiyerleri başka şekilde belirtilmediği sürece $30{ }^{\circ} \mathrm{C}^{\prime}$ de 48 saat inkübe edilmiştir (Memmert BE600, Germany).

\subsection{Başlangıç pH derecelerinin EPS üretimine etkisi}

En yüksek EPS üretiminin yapıldığı optimum $\mathrm{pH}^{\prime} ı n$ bulunması için $100 \mathrm{mg} / \mathrm{l}$ boya içeren ortam pH'ları 6, 7,8 ve 9 değerlerine ayarlanmıştır.

\subsection{Başlangıç Remazol Blue konsantrasyonlarının ve farklı sıcaklık derecelerinin EPS üretimine etkisi}

Artan Remazol Blue konsantrasyonlarının EPS üretimine etkisinin araştırıldığı deneylerde, Micrococcus sp. daha önce belirlenen optimum $\mathrm{pH}$ derecesinde ayarlanmış ve $100 \mathrm{mg} / \mathrm{l}, 200 \mathrm{mg} / \mathrm{l}, 300$ $\mathrm{mg} / \mathrm{l}$ ve $400 \mathrm{mg} / \mathrm{l}$ Remazol Blue içeren besiyerlerinde inkübe edilmiştir.

Farklı başlangıç Remazol Blue konsantrasyonlarının ve sıcaklık derecelerinin Micrococcus sp. tarafından 
üretilen EPS miktarına birlikte etkisini görmek için 100-400 mg/l Remazol Blue içeren ve içermeyen Nutrient Agar besiyerleri hazırlanmıştır. Sıcaklık dereceleri 20, 30 ve $40{ }^{\circ} \mathrm{C}^{\prime}$ lere ayarlanarak bakteri bu ortamlarda geliştirilmiştir.

\subsection{Farklı inkübasyon sürelerinin EPS üretimine etkisi}

İnkübasyon süresinin EPS üretimine etkisinin araştırılması için bakteri, en yüksek EPS ürettiği ortamda (pH 6; $100 \mathrm{mg} / \mathrm{l}$ Remazol Blue; $40{ }^{\circ} \mathrm{C}$ ) 48, $72,96,120,144$ ve 168 saat boyunca geliştirilmiştir. EPS analizleri bu inkübasyon sürelerinin sonunda gerçekleştirilmiştir.

\subsection{Analitik yöntemler}

\subsection{EPS izolasyon ve ölçümü}

EPS izolasyonu, Cérantola et al. (2000) yaptığı çalışmaya göre gerçekleştirilmiştir. Bu amaçla agar yüzeyindeki koloniler cam çubukla toplanmış, tartılmış (0.1 g) ve fizyolojik tuzlu ortama alınmıştır. Süspansiyon $100{ }^{\circ} \mathrm{C}$ 'de 15 dakika kaynatılmıştır. Karışıma soğutulduktan sonra, son hacim \%4 (w/v) olacak şekilde trikloroasetik asit (TCA) eklenmiştir. $\mathrm{Bu}$ aşamadan sonra, $10,000 \times \mathrm{g}$ de ve $4{ }^{\circ} \mathrm{C}^{\prime}$ de 30 dakika boyunca santrifüj yapılmıştır. Süpernatant alınarak soğuk etanol ile karıştırılmıştır. Bu karışım $10,000 \times$ g'de ve $4{ }^{\circ} C^{\prime}$ de 30 dakika boyunca santrifüjlenmiştir. İzolasyon bir kez daha tekrarlanmıştır. Çökelti alınarak distile suda çözülmüştür. EPS içindeki karbohidrat içeriği fenol$\mathrm{H}_{2} \mathrm{SO}_{4}$ metodu kullanılarak, glukoz standartına göre bulunmuştur (Dubois et al. 1956).

\subsection{Istatistik analizleri}

Bütün denemeler, üçlü tekrarlar halinde gerçekleştirilmiştir. Veriler, standart sapmaların hesaplanıp belirtilmesiyle ifade bulmuştur $( \pm S E)$.

\section{Bulgular}

\subsection{Başlangıç $\mathrm{pH}$ derecelerinin EPS üretimine etkisi}

Remazol Blue içeren ortamların pH'ları 6-9 aralığında değiştirilerek, $\mathrm{pH}^{\prime} ı$ Micrococcus sp. tarafından üretilen EPS miktarına etkisi incelenmiştir. Ortamın alkalilik derecesi arttıkça bakteri tarafından üretilen EPS miktarının azaldığı Çizelge 1'de gösterilmiştir. En yüksek EPS oluşumunun $\mathrm{pH} \quad$ 6'da $189.7 \mathrm{mg} / \mathrm{l}$ olduğu bulunmuştur. Ortamın pH derecesi 9'a çıkarıldığında EPS üretiminin $104.3 \mathrm{mg} / \mathrm{l}$ 'ye düştüğü gözlemlenmiştir.

Çizelge 1. Farklı pH derecelerinin Micrococcus sp. tarafından üretilen EPS miktarına etkisi (Başlangıç Remazol Blue konsantrasyonu: $100 \mathrm{mg} / \mathrm{l}$; T: 30 ㅇ; inkübasyon süresi: 48 saat)

\begin{tabular}{cc}
\hline $\mathrm{pH}$ & EPS $(\mathrm{mg} / \mathrm{l})$ \\
\hline 6 & $189.7 \pm 6.0$ \\
\hline 7 & $140.6 \pm 9.1$ \\
\hline 8 & $116.0 \pm 2.5$ \\
\hline 9 & $104.3 \pm 11.5$
\end{tabular}

\subsection{Başlangıç Remazol Blue konsantrasyonları ve farklı sıcaklık derecelerinin EPS üretimine etkisi}

Başlangıç Remazol Blue konsantrasyonlarının Micrococcus sp. tarafından üretilen EPS miktarına etkisi, $30{ }^{\circ} \mathrm{C}$ ve $\mathrm{pH} 6^{\prime} \mathrm{da}$ yapılan denemelerle belirlenmiştir. Artan Remazol Blue konsantrasyonlarının EPS üretimine etkisi Şekil 1'de verilmiştir. $\mathrm{Bu}$ deneylerde, Remazol Blue konsantrasyonunun artmasıyla bakteri tarafından oluşturulan EPS miktarı da artmıştır. Boya içermeyen ortamda üretilen EPS miktarı $186.7 \mathrm{mg} / \mathrm{I}$ olarak tespit edilirken, EPS oluşumu Remazol Blue konsantrasyonunun 200 mg/l'ye kadar arttırılmasıyla artmıştır. Micrococcus sp. tarafından oluşturulan en yüksek EPS miktarları, 100 mg/l Remazol Blue bulunan ortamda, 189.7 mg/l; 200 $\mathrm{mg} /$ Remazol Blue bulunan ortamda, $234.8 \mathrm{mg} / \mathrm{l}$ olarak bulunmuştur. Remazol Blue konsantrasyonu 
daha da arttırıldığında üretilen ekstrasellüler polimer miktarı azalmıştır.

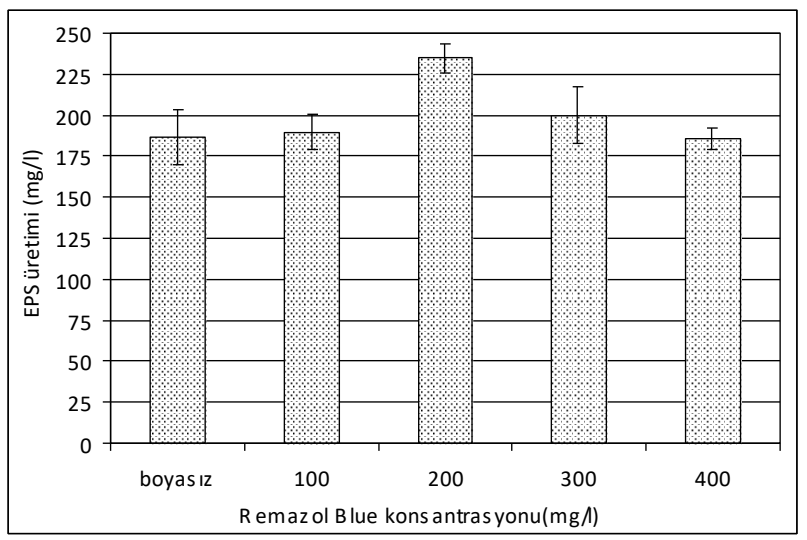

Şekil 1. Başlangıç Remazol Blue konsantrasyonlarının Micrococcus sp. tarafından üretilen EPS miktarına etkisi (pH: 6; T: $30^{\circ} \mathrm{C}$; inkübasyon süresi: 48 saat)

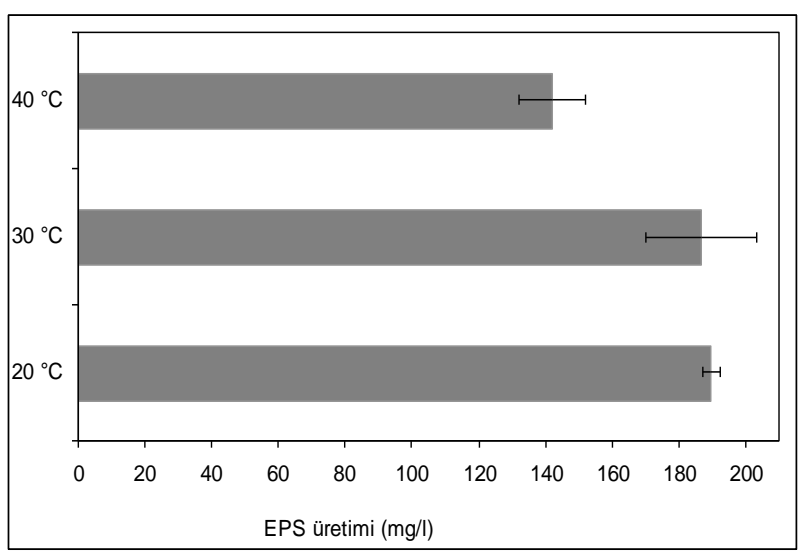

Şekil 2. Farklı başlangıç sıcaklıklarının Remazol Blue içermeyen ortamda Micrococcus sp. tarafından üretilen EPS miktarına etkisi ( $\mathrm{pH}$ : 6; inkübasyon süresi: 48 saat)

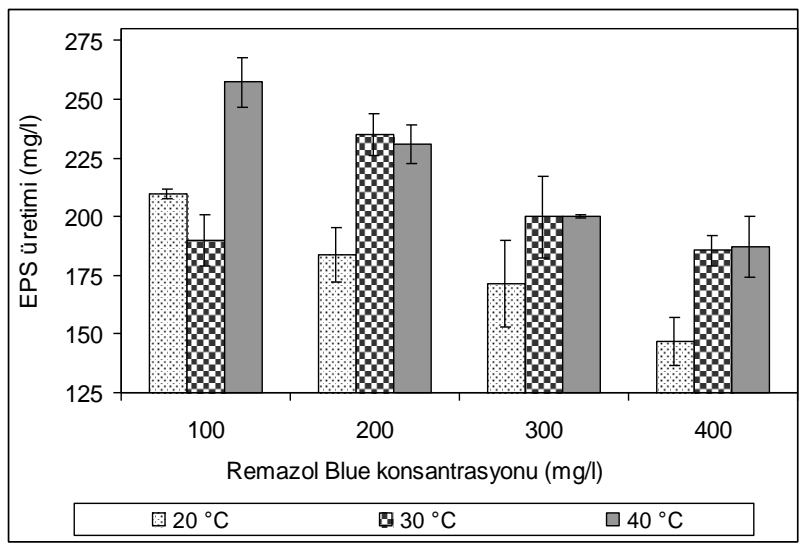

Şekil 3. Başlangıç Remazol Blue konsantrasyonlarının ve sıcaklık derecelerinin Micrococcus sp. tarafından üretilen
EPS miktarına birlikte etkisi ( $\mathrm{pH}$ : 6; inkübasyon süresi: 48 saat)

Farklı sıcaklık derecelerinin EPS üretimine etkisi pH'sı 6'ya ayarlanmış, Remazol Blue içeren ve içermeyen ortamlarda belirlenmiştir (Şekil 2 ve 3).

Şekil 2'de özetlendiği gibi, Remazol Blue bulunmayan besiyerinde geliştirilen bakteri, en düşük sıcaklık derecesinde $\left(20^{\circ} \mathrm{C}\right), 189.8 \mathrm{mg} / \mathrm{l}$ olarak ölçülen miktarda EPS üretmiştir. Sıcaklık derecesi arttırıldığında mikroorganizma tarafından oluşturulan polimerin azaldığı tespit edilmiştir. Sıcaklık $30{ }^{\circ} \mathrm{C}$ olduğunda üretilen EPS bir miktar azalarak $186.7 \mathrm{mg} / \mathrm{l}$ olarak bulunmuştur. Ortamın sıcaklığı daha da arttırıldığında $\left(40{ }^{\circ} \mathrm{C}\right)$ bakterinin yaptığı EPS, $142.2 \mathrm{mg} / \mathrm{l}$ olarak tespit edilmiştir.

Başlangıç Remazol Blue konsantrasyonlarının ve sıcaklık derecelerinin Micrococcus sp. tarafından üretilen EPS miktarına birlikte etkisi Şekil 3'te özetlenmiştir. Sıcaklık derecesi $20{ }^{\circ} \mathrm{C}$ olduğunda, artan Remazol Blue konsantrasyonlarında bakteri en yüksek EPS üretmini $100 \mathrm{mg} / \mathrm{l}$ Remazol Blue konsantrasyonda hazırlanan Nutrient Agar besiyerinde yapmıştır $(209.6 \mathrm{mg} / \mathrm{l})$. Bu sıcaklıkta yapılan denemelerde, Remazol Blue konsantrasyonunun $100 \mathrm{mg} / \mathrm{l}$ den daha da arttırılması ile üretilen EPS miktarı artan boya konsantrasyonlarından olumsuz yönde etkilenmiştir. Oluşturulan polimerin miktarı kirleticinin arttırılmasıyla azalmış ve $200 \mathrm{mg} / \mathrm{l}$ Remazol Blue içeren ortamda $183.9 \mathrm{mg} /$ l olarak; 300 ve $400 \mathrm{mg} / \mathrm{l}$ Remazol Blue içeren ortamlarda sırasıyla $171.2 \mathrm{mg} / \mathrm{l}$ ve $146.7 \mathrm{mg} / \mathrm{l}$ olarak belirlenmiştir. Ortam sıcaklığının $30{ }^{\circ} \mathrm{C}$ olduğu besiyerinde geliştirilen Micrococcus sp. en yüksek miktarda ekstrasellüler polimeri $200 \mathrm{mg} / \mathrm{l}$ Remazol Blue içeren ortamda üretmiştir $(234.8 \mathrm{mg} / \mathrm{l})$. Aynı sıcaklık koşulunda yapılan denemelerde, $20{ }^{\circ} \mathrm{C}$ 'de gerçekleştirilen denemelere benzer olarak kirletici miktarının daha da arttırılması ile üretilen EPS miktarı da azalmıştır. Sıcaklığın $30{ }^{\circ} \mathrm{C}$ olduğu ortamlarda, Remazol Blue konsantrasyonu 300 mg/l olduğunda üretilen EPS miktarı $200.0 \mathrm{mg} / \mathrm{l}$ olarak, $400 \mathrm{mg} / \mathrm{l}$ olduğunda da ise $185.5 \mathrm{mg} / \mathrm{l}$ olarak tespit edilmiştir.

Mikroorganizmanın, denenen diğer sıcaklıklara göre sıcaklığın $40^{\circ} \mathrm{C}$ olduğu deneylerde en fazla miktarda EPS ürettiği tespit edilmiştir. Bu sıcaklıkta geliştirilen 
Micrococcus sp., Remazol Blue konsantrasyonunun $100 \mathrm{mg} / \mathrm{l}$ olduğu besiyerinde en yüksek kapasite ile EPS üretmiştir $(257.2 \mathrm{mg} / \mathrm{l})$. Remazol Blue konsantrasyonu $200 \mathrm{mg} / \mathrm{l}$ olduğunda oluşan ekstraselüller polimer miktarı $230.9 \mathrm{mg} / \mathrm{l}$, boya miktarı 300 mg/l'ye çıkarıldığında ise bu değer 200.0 $\mathrm{mg} / \mathrm{l}$ olarak tespit edilmiştir. En yüksek boya konsantrasyonunda $(400 \mathrm{mg} / \mathrm{l})$ ve $40{ }^{\circ} \mathrm{C}$ 'deki denemelerde, aynı kirletici konsantrasyonundaki diğer sıcaklıklarda oluşturulan EPS miktarına göre daha fazla miktarda ekstrasellüler polimer üretildiği belirlenmiştir $\quad(187.0 \quad \mathrm{mg} / \mathrm{l})$. Boya konsantrasyonunun artmasıyla, test bakterisi toksik kirleticiden olumsuz yönde etkilenmiş ve daha az miktarda EPS üretmiştir.

\subsection{Farklı inkübasyon sürelerinin EPS üretimine etkisi}

İnkübasyon süresinin EPS üretimine etkisini belirlemek için 6 farklı inkübasyon süresi (48-168 saat) denenmiştir. Bakteri, en yüksek miktarda polimer oluşturduğu ortamda $\left(\mathrm{pH} 6,40^{\circ} \mathrm{C}, 100 \mathrm{mg} / \mathrm{l}\right.$ Remazol Blue konsantrasyonu) farklı inkübasyon sürelerinde geliştirilmiştir. Altı farklı inkübasyon süresi sonunda ölçülen EPS miktarları Şekil 4'te gösterilmiştir.

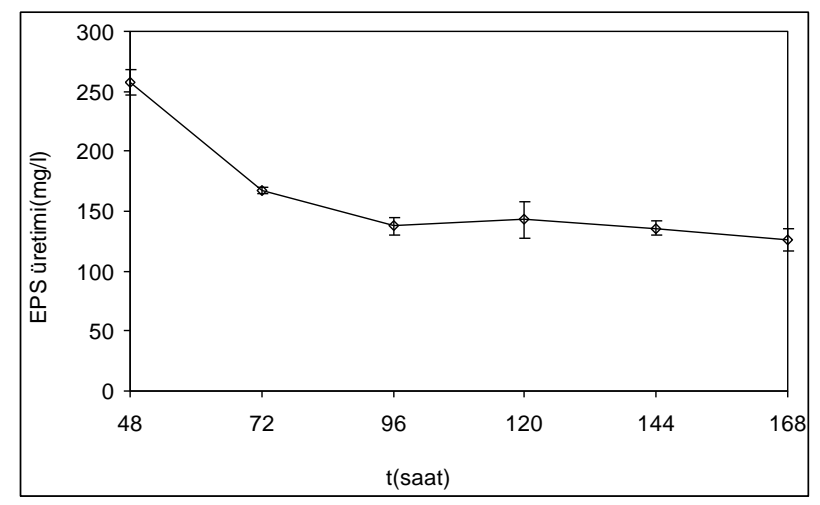

Şekil 4. Farklı inkübasyon sürelerinin Micrococcus sp. tarafından üretilen EPS miktarına etkisi (pH: 6; T: 40 ㅇ; 100 mg/l Remazol Blue; inkübasyon süresi: 48-168 saat)

Micrococcus sp. en yüksek miktarda polimer oluşumunu 48 saat inkübasyon süresi sonunda gerçekleştirmiştir $(257.2 \mathrm{mg} / \mathrm{l})$. Yetmişiki saat sonunda bakteri tarafından üretilen EPS miktarı 167.0 mg/l, 96 saat inkübasyon süresi sonunda ise
$137.5 \mathrm{mg} / \mathrm{l}$ olarak belirlenmiştir. İnkübasyon süresinin daha da arttırılması ile üretilen EPS miktarı az miktarda artsa da (142.9 mg/l), süre uzadığında polimer üretiminin değişmeden kaldığı tespit edilmiştir. Denenen diğer iki inkübasyon süresi sonunda da (144 ve 168 saat) üretilen EPS miktarları sırasıyla $135.9 \mathrm{mg} / \mathrm{l}$ ve $126.1 \mathrm{mg} / \mathrm{l}$ olarak ölçülmüştür.

\section{Tartışma ve Sonuç}

Ekstrasellüler polimerler bakteriler için koruyucu bir bariyer gibi görev yapmaktadırlar. EPS üretim miktarı, ağır metal konsantrasyonu, tuz iyonları, pH derecesi, sıcaklık, oksijen konsantrasyonu veya besiyeri bileşimi gibi birçok farklı koşullardan etkilenmektedir (Nicolaus et al. 2002, Leppard et al. 2003, Guibaud et al. 2005, Nandal et al. 2005, Velasco et al. 2006, Gupta and Diwan 2017).

Yapılan çalışmada da Micrococcus sp. Remazol Blue gibi bir toksik kirletici varlığında hem gelişmekte hem de fazla miktarda EPS üretmektedir. Boyasız ortama göre sentezlenen EPS miktarının boya içeren ortamlarda artması bakterinin kirleticiye karşı koyduğunu, toksik etkiden kurtulmak ve canlılığını devam ettirmek için ekstrasellüler polimer üretimini arttırdığını göstermektedir (Şekil 1).

Micrococcus sp. tarafından üretilen EPS miktarı farklı ortam koşullarından etkilenmiştir. Rhizobium sp. ile yapılan bir çalışmada, sıcaklık derecesi arttırıldığında mikroorganizma tarafından üretilen EPS miktarının da arttığı gösterilmiştir (Nandal et al. 2005). Yapılan çalışmada da Remazol Blue gibi toksik bir kirletici bulunan ortamda sıcaklığın $20^{\circ} \mathrm{C}$ 'den 30 ${ }^{\circ} \mathrm{C}$ ve $40{ }^{\circ} \mathrm{C}$ 'lere arttırılması ile bakteri tarafından oluşturulan ekstrasellüler polimer artmıştır. EPS miktarının bu şekilde artması, Micrococcus sp.'nin yüksek sıcaklık ortamında yaşayabilme toleransının çok fazla olduğunu göstermektedir (Şekil 3).

Daha önce Micrococcus sp. ile yapılan bir diğer çalışmada, $\mathrm{Cr}(\mathrm{VI})$ gibi bir kirleticiye maruz bırakılan bakterinin EPS üretim miktarı belirlenmiştir (Kılıç and Dönmez 2008). Aynı çalışmada en yüksek EPS üretiminin $100 \mathrm{mg} / \mathrm{l} \mathrm{Cr}(\mathrm{VI})$ içeren ortamda 72 saat 
inkübasyon süresi sonunda olduğu, inkübasyon süresinin daha da arttırılmasıyla EPS oluşumunun azaldığı belirlenmiştir. Remazol Blue gibi toksik bir kirletici ile gerçekleştirilen bu çalışmada da, inkübasyon süresinin uzaması ile bakteri tarafından üretilen EPS miktarının azaldığı görülmüştür.

Çalışmada elde edilen veriler, deri sanayii atık sularından izole edilen Micrococcus sp. bakterisinin yüksek konsantrasyonda boya ve yüksek sıcaklık gibi stres koşullarında arttırdığı EPS üretimi ile kolaylıkla canlılığını sürdürebildiğini göstermiştir. Bu özellikleri ile Micrococcus sp.'nin boyalı atık suların biyolojik arıtımında kullanılabileceği sonucuna ulaşılmıştır.

\section{Kaynaklar}

Aksu, Z., 2005. Application of biosorption for the removal of organic pollutants: a review. Process Biochemistry, 40, 997-1026.

Aksu, Z. and Dönmez, G., 2005. Combined effects of molasses sucrose and reactive dye on the growth and dye bioaccumulation properties of Candida tropicalis. Process Biochemistry, 40, 1437-44.

Allegre, C., Moulin, P., Maisseu, M. and Charbit, F., 2006. Treatment and reuse of reactive dyeing effluents. Journal of Membrane Science, 269, 15-34.

Bouraie, M.E., Din, W.S.E., 2016. Biodegradation of reactive black 5 by Aeromonas hydrophila strain isolated fromdye-contaminated textile wastewater. Sustainable Environment Research 26(5), 209-216.

Cérantola, S., Bounéry, J., Segonds, C., Marty, N. and Montrozie, H., 2000. Exopolysaccharide production by mucoid and non-mucoid strains of Burkholderia cepacia. FEMS Microbiology Letters, 185, 243-46.

Crini, G. 2006., Non-conventional low-cost adsorbents for dye removal: A review. Bioresource Technology, 97, 1061-85.

Chen, B. 2002., Understanding decolorization characteristics of reactive azo dyes by Pseudomonas luteola: toxicity and kinetics. Process Biochemistry, 38, 437-46.

Dubois, M., Gilles, K.A., Hamilton, J.K., Rebers, P.A. and Smith, F. 1956., Colorimetric method for determination of sugars and related substances. Analytical Chemistry, 28, 350-56.

Flemming, H-C., Wingender, J., Szewzyk,U., Steinberg, P., Scott A. Rice, S.A. and Kjelleberg, S., 2016. Biofilms: an emergent form of bacterial life. Nature Reviews Microbiology, 14, 563-75.
Guibaud, G., Comte, S., Bordas, F., Dupuy, S. and Baudu, M., 2005. Comparison of the complexation potential extracellular polymeric substances (EPS), extracted from activated sludges and produced by pure bacteria strains, for cadmium, lead and nickel. Chemosphere, 59, 629-638.

Gupta, P. and Diwan, B. 2017. Bacterial Exopoloysaccaharide mediated heavy metal removal: A review on biosynthesis, mechanism and remediation strategies. Biotechnology Reports, 13, 58-71.

Iyer, A., Mody, K. and Jha, B., 2004. Accumulation of hexavalent chromium by an exopolysaccharide producing marine Enterobacter cloaceae. Marine Pollution Bulletin, 49, 974-77.

Khehra, M.S., Saini, H.S., Sharma, D.K., Chadha, B.S. and Chimni, S.S., 2006. Biodegradation of azo dye C.I. Acid Red 88 by an anoxiceaerobic sequential bioreactor. Dyes and Pigments, 70, 1-7.

Kılıç, N. and Dönmez, G., 2007. Hexavalent chromium by Micrococcus sp. isolated from tannery wastewaters. Fresenius Environmental Bulletin, 16(12a), 1571-1577.

Kılıç, N.K., Nielsen, J.L., Yüce, M. and Dönmez, G., 2007. Characterization of a simple bacterial consortium for effective treatment of wastewaters with reactive dyes and $\mathrm{Cr}(\mathrm{VI})$. Chemosphere, 67, 826-31.

Kılıç, N. and Dönmez, G., 2008. Environmental conditions affecting exopolysaccharide production by Pseudomonas aeruginosa, Micrococcus sp., Ochrobactrum sp. Journal of Hazardus Materials, 154, 1019-24.

Leppard, G.G., Droppo, I.G., West, M.M. and Liss, S.N., 2003. Compartmentalization of metals within the diverse collodial matrices comprising activated sludge microbial flocs. Journal of Environmental Quality, 32, 2100-08.

Lodato, A., Alfieri, F., Olivieri, G., Di Donato, A., Marzocchella, A. and Salatino, P., 2007. Azo-dye conversion by means of Pseudomonas sp. OX1. Enzyme and Microbial Technology, 41, 646-652.

Mishra, S. and Maiti, A., 2018. The efficacy of bacterial species to decolourise reactive azo, anthroquinone and triphenylmethane dyes from wastewater: a review. 2018. Environmental Science and Pollution Research (2018) 25, 8286-8314.

Mohite, B.V., Koli, S.H., Narkhede, C.P., Patil, S.N., Patil, S.V., 2017. Prospective of Microbial Exopolysaccharide for Heavy Metal Exclusion. Applied Biochemistry and Biotechnology, 183, 582-600.

Moosvi, S., Kher, X., Madamwar, D., 2007. Isolation, characterization and decolorization of textile dyes by a mixed bacterial consortium JW-2. Dyes and Pigments 74, 723-729. 
Nicolaus, B., Lama, L., Panico, A., Moriello, V.S., and Romano, I., 2002. Production and characterization of exopolysaccharides extcreted by thermophilic bacteria from shallow, marine hydrothermal vents of flegrean areas (Italy). Systematic and Applied Microbiology, 25, 319-325.

Nandal, K., Sehrawat, A.R., Yadav, A.S., Vashishat, R.K. and Boora, K.S., 2005. High temperature-induced changes in exopolysaccharides, lipopolysaccharides and protein profile of heatresistant mutants of Rhizobium sp. (Cajanus). Microbial Bioresearch, 160, 367-373.

Ozdemir, G., Ozturk, T., Ceyhan, N., Isler, R. and Cosar, T., 2003. Heavy metal biosorption by biomass of Ochrobactrum antropi producing exopolysaccharide in activated sludge. Bioresource Technology, 90, 71-74.

Sadettin, S. and Dönmez, G., 2006. Bioaccumulation of reactive dyes by thermophilic cyanobacteria. Process Biochemistry, 41, 836-841.

Shah, V., Garg, N. and Madamwar, D., 1999. An integrated process of textile dye removal and hydrogen evolution using cyanobacterium, Phormidium valderianum. World of Journal Microbiology and Biotechnology, 17, 499-504.

Velasco, S., Arsköld, E., Paese, M., Grage, H., Irastorza, A., Radström, P. and van Niel, E.W.J., 2006. Environmental factors influencing growth of and exopolysaccharide formation by Pedicoccus parvulus 2.6. International Journal of Food Microbiology, 111, 252-258.

Zhang, D., Wang, J. and Pan, X., 2006. Cadmium sorption by EPSs produced by anaerobic sludge under sulfate-reducing conditions. Journal of Hazardous Materials, B138, 589-593. 